\title{
NITROGEN AVAILABILITY, LEAF LIFE SPAN AND NITROGEN CONSERVATION MECHANISMS IN LEAVES OF TROPICAL TREES
}

\author{
Guilherme Nascimento Corte ${ }^{1}$; Patrícia Macchiaverni ${ }^{1}$; Inácio Maria Dal Fabbro²; Claudia \\ Regina Baptista Haddad ${ }^{1 *}$ \\ ${ }^{1}$ UNICAMP/Instituto de Biologia - Depto. de Biologia Vegetal, C.P.6109 - 13083-970 - Campinas, SP - Brasil. \\ ${ }^{2}$ UNICAMP/Faculdade de Engenharia Agrícola. \\ *Corresponding author <chaddad@unicamp.br>
}

\begin{abstract}
Evergreen species of temperate regions are dominant in low-nutrient soils. This feature is attributed to more efficient mechanisms of nutrient economy. Nevertheless, the cashew (Anacardium occidentale-Anacardiaceae), a deciduous species, is native to regions in Brazil with sandy soil, whilst the annatto (Bixa orellana- Bixaceae), classified as an evergreen species native to tropical America, grows spontaneously in regions with more humid soils. Evergreens contain robust leaves that can resist adverse conditions for longer. The physical aspects of the leaves and mechanisms of nutrient economy between the two species were compared, in order to verify whether the deciduous species had more efficient mechanisms that might explain its occurrence in regions of low soil fertility. The mechanisms of nitrogen economy were also compared for the two species at available concentrations of this nutrient. The following were analysed: (i) leaf life span, (ii) physical leaf characteristics (leaf mass per area, and rupture strain), (iii) nitrogenous compounds (nitrogen, chlorophyll, and protein), (iv) nitrogen conservation mechanisms (nitrogen resorption efficiency, resorption proficiency, and use efficiency), and (v) nitrogen conservation mechanisms under different availability of this mineral. The higher values of leaf mass per area and leaf rupture strain found in $A$. occidentale were related to its longer leaf life span. A. occidentale showed lower concentrations of nitrogen and protein in the leaves than B. orellana. Under lower nitrogen availability, $A$. occidentale had higher nitrogen resorption proficiency, nitrogen use efficiency and leaf life span than B. orellana. These characteristics may contribute to the adaptation of this species to sandy soils with low nitrogen content.

Key words: leaf deciduity, nitrogen resorption proficiency, nitrogen use efficiency, leaf rupture strain

\section{DISPONIBILIDADE DE NITROGÊNIO, LONGEVIDADE FOLIAR E MECANISMOS DE CONSERVAÇÃO DE NITROGÊNIO EM FOLHAS DE ESPÉCIES ARBÓREAS TROPICAIS}

\begin{abstract}
RESUMO: Perenifólias de clima temperado são dominantes em solos pouco férteis. Essa característica é atribuída a mecanismos mais eficientes de economia de nutrientes. O cajueiro (Anacardium occidentale - Anacardiaceae), uma espécie decídua, é nativo de região do Brasil com solos arenosos, enquanto que o urucuzeiro (Bixa orellana - Bixaceae), uma perenifólia, nativa da América tropical, é espontâneo em regiões com solo mais úmido e fértil. As perenifólias apresentam folhas robustas, adaptadas a resistir a adversidades por mais tempo. Compararam-se aspectos físicos das folhas e mecanismos de economia de nutrientes entre as duas espécies, a fim de verificar se a espécie decídua apresenta mecanismos mais eficientes, que expliquem sua ocorrência em locais pouco férteis. Foram também comparados os mecanismos de economia de nitrogênio sob disponibilidades diferentes deste nutriente. Foram avaliados: (i) longevidade foliar, (ii) características físicas das folhas (massa por área e tensão de ruptura), (iii) concentração de compostos nitrogenados nas folhas (nitrogênio, clorofila e proteínas), (iv) mecanismos de conservação de nitrogênio (eficiência de reaproveitamento, proficiência de reaproveitamento e eficiência do uso), (v) mecanismos de conservação de nitrogênio sob disponibilidades diferentes deste elemento. A maior longevidade foliar de A. occidentale foi relacionada a valores maiores de massa foliar específica e tensão de ruptura foliar. A. occidentale apresentou menores concentrações de nitrogênio e proteínas. Sob menor disponibilidade de nitrogênio A. occidentale apresentou maiores valores de proficiência de reaproveitamento e eficiência do uso de nitrogênio e maior longevidade foliar. Essas características podem ter contribuído para a adaptação dessa espécie a locais com solos arenosos mais pobres em nitrogênio. Palavras-chave: deciduidade foliar, proficiência de reaproveitamento de nitrogênio, eficiência do uso de nitrogênio, tensão de ruptura da folha
\end{abstract}

Sci. Agric. (Piracicaba, Braz.), v.66, n.6, p.812-818, November/December 2009 


\section{INTRODUCTION}

In low fertility soils the dominant species tend to be evergreens (Ishida et al., 2006). The longer life span of leaves of evergreen species and their lower nutrient content are important in the colonization of low fertility soils (Carrera et al., 2003). However, generally, in the neotropical region, evergreen species produce leaves intermittently and leaf fall is not concentrated in a specific time of the year (Morellato et al., 2000), but may change continuously. Therefore, the fact that a species is an evergreen does not necessarily mean that its leaves have a longer life span than those from deciduous species. In fact, the differences found between evergreen and deciduous species are due mainly to differences in the leaf life span of the two types of plants (Reich et al., 1992).

Evergreens tend to have a higher leaf mass per area (Ishida et al., 2006) due to thicker leaf blades and a larger lignified area (Read et al., 2000). This allows these leaves to resist adverse conditions for a greater length of time (Gates 1914 in Chabot \& Hicks, 1982).

Removal of nutrients from leaves prior to abscission and their transport to other organs is known as nutrient resorption (Wright \& Westoby, 2003). The greater the resorption efficiency, the more nitrogen is reused by the plant (Hikosaka, 2005). This is an adaptation of some species to low fertility soils (Pugnaire \& Chapin, 1993). Therefore, evergreens are likely to exhibit greater resorption efficiency in comparison to deciduous species. Nevertheless, there is no consensus when comparing these two groups of plants (Lal et al., 2001; Diehl et al., 2003). The relationship between nutrient resorption efficiency and soil fertility is also controversial (Carrera et al., 2003; Lima et al., 2006b). Resorption proficiency, the absolute value by which nutrients are reduced in senescent leaves is a more objective measure of the degree by which the plants minimize nutrient loss (Killingbeck, 1996). The dominance of evergreen species in low fertility habitats may also be explained by their efficiency in nutrient use (Chabot \& Hicks, 1982). There are indications that this variable also increases as soil nutrients decrease (Distel et al., 2003).

Often, little is known about the relationship between leaf life span and conservation of nutrients for tropical trees, even though such knowledge is important for the recovery of degraded areas with native species. In this study, two tree species were examined: the cashew (Anacardium occidentale L Anacardiaceae.) and the annatto (Bixa orellana Benth - Bixaceae). Although A. occidentale is a deciduous species and grows in several types of soils, it is native to regions of Brazilian sandy soils. B. orellana is an evergreen, but it grows preferentially in more humid soils. It is native to tropical America showing spontaneous growth in the Amazon forest (Lorenzi, 2000). The two species were chosen because when their leaf deciduousness is analyzed with regard to the fertility of their native habitats, it was found that they show opposite behaviors to those described in the literature. The aim of this study was to compare the two species in order to verify if more efficient mechanisms of nitrogen conservation can explain the existence of the deciduous species in low fertility soil.

\section{MATERIALAND METHODS}

Characterization of the species and cultivation site

The study was carried out from July of 2002 to July of 2004, in Campinas, São Paulo State, Brazil $\left(22^{\circ} 49^{\prime} \mathrm{S}, 47^{\circ} 06^{\prime} \mathrm{W}\right.$, and $670 \mathrm{~m}$ of altitude). The soil is a Rhodic Eutrudox. The climate is characterized by a dry, cold season from April to September and a wet, warm season from October to March. During the dry season the mean precipitation \pm standard deviation is $44 \pm 17 \mathrm{~mm}$ over six month periods. The mean minimum temperature is $14.3 \pm 1.9^{\circ} \mathrm{C}$ and the mean maximum temperature is $26.5 \pm 1.6^{\circ} \mathrm{C}$, over the same period. In the wet season the mean rainfall is $185 \pm 50$ $\mathrm{mm}$ and the mean minimum temperature is $18.9 \pm$ $0.9^{\circ} \mathrm{C}$ and mean maximum temperature is $29.6 \pm$ $0.4^{\circ} \mathrm{C}$ (data from http://www.agritempo.gov.br, years: 1984-2004). The transitional periods (March-April and September-October) are characterized by variation in temperature and precipitation. The strongest winds occur from August to November (Morellato \& LeitãoFilho, 1996).

The species used were Anacardium occidentale L (Anacardiaceae) and Bixa orellana Benth (Bixaceae). The first experiment was carried out on mature trees, approximately fifteen years old, growing directly on a Rhodic Eutrudox. In the second experiment, the individuals of both species were planted in pots with two types of substrate. In the first experiment the study was carried out with five individuals per species using selected leaves (three for each individual) without visible signs of disease or herbivory. The trees of $A$. occidentale were grown in Campinas, SP, Brazil, where the soil total nitrogen content was $3.2 \mathrm{~g} \mathrm{~kg}^{-1}$ (analyzed by the Kjeldahl method -Bremner, 1996). The trees of $B$. orellana were grown in an experimental farm in Campinas, SP, Brazil, where the soil total nitrogen content was $2.6 \mathrm{~g} \mathrm{~kg}^{-1}$.

Mature green leaves were fully expanded and completely green. Senescent leaves were completely yellow and dropped when touched. Total chlorophyll concentration was determined in mature green $\left(7.86 \mu \mathrm{g} \mathrm{mg}^{-1}\right.$ 
dry mass for $A$. occidentale and $11.16 \mu \mathrm{g} \mathrm{mg}^{-1}$ dry mass for $B$. orellana) and senescent leaves $\left(3.07 \mu \mathrm{g} \mathrm{mg}^{-1}\right.$ dry mass for $A$. occidentale and $1.60 \mu \mathrm{g} \mathrm{mg}^{-1}$ dry mass for $B$. orellana) in order to find the point in which there was a decrease in its concentration and thus establish the beginning of senescence (Smart, 1994) and nitrogen resorption processes. Mature green leaves and senescent leaves were collected at the same time for both species (Table 1).

The leaf life span was monitored using dated plastic tape placed around the petioles of very young leaves ( $1 \mathrm{~cm}$ long petioles) (Lima et al., 2006a). The leaves of both species were dated at same time. Leaf abscission was observed daily.

\section{Physical aspects of leaves}

The leaf mass per area was calculated using the formula: $\mathrm{LMA}=\mathrm{DM}$ mature green leaves $/ \mathrm{A}_{\text {mature green leaves }}\left(\mathrm{g} \mathrm{cm}^{-2}\right)$, where $\mathrm{DM}=$ dry mass and $\mathrm{A}=$ leaf area.

Dry mass was obtained after leaves had been kept in an oven at $60^{\circ} \mathrm{C}$ for seven days. The leaf area was obtained for fresh leaves using a LI-COR instrument, model LI-300.

The rupture of leaves was determined through strain failure by carrying out uniaxial traction tests on mature green leaves. Leaves were taken to the laboratory in humidity chambers to maintain their turgidity. They were cut into similarly-sized square strips and their edges were attached to hooks following the procedure in Piedade et al. (2001). The hooks were attached to a testing press, model TA 500, Lloyd Instruments and to a data acquisition system. Strain failure was then calculated as reported by Dal Fabbro et al. (1980). The distance between hooks was fixed to 9 $\mathrm{cm}$ and the rupture strain test was carried out at a velocity of $0.6 \mathrm{~mm} \mathrm{~s}^{-1}$. The software used was Nexigen 3.0.

\section{Nitrogenous compounds}

Chlorophyll was determined according to Hiscox \& Israelstam (1979). Portions of leaves (20 mg fresh mass) were immersed in dimethyl-sulphoxide (DMSO) in sealed tubes kept in the dark. The tubes were incubated in a water-bath at $65^{\circ} \mathrm{C}$ for $30 \mathrm{~min}$ and cooled to room temperature. Total chlorophyll content was calculated according to Lichtenthaler \& Wellburn (1983). For extraction of total soluble proteins the leaves were macerated using liquid nitrogen and extracted with $0.1 \mathrm{~N} \mathrm{NaOH}$. After standing for $24 \mathrm{~h}$, the extract was centrifuged at $2000 \mathrm{~g}\left(15 \mathrm{~min}, 4^{\circ} \mathrm{C}\right)$. The supernatant was used for the determination of total proteins (Bradford, 1976).

\section{Determination of total nitrogen in the leaves and nitrogen conservation mechanisms}

The determination of the total nitrogen content was made using samples of $100 \mathrm{mg}$ from leaves dried at $60^{\circ} \mathrm{C}$ for seven days. The leaf tissue was placed in digestion tubes, containing $1 \mathrm{~g}$ of catalyst $(100 \mathrm{~g}$ of $\mathrm{K}_{2} \mathrm{SO}_{4}, 10 \mathrm{~g}$ of $\mathrm{CuSO}_{4} .5 \mathrm{H}_{2} \mathrm{O}$ and $1 \mathrm{~g}$ of Se), $3 \mathrm{~mL}$ of concentrated sulphuric acid and $1 \mathrm{~mL}$ of hydrogen peroxide $\left(\mathrm{H}_{2} \mathrm{O}_{2}\right)$. Samples were digested at $360^{\circ} \mathrm{C}$ and their $\mathrm{N}$ content determined by the Kjeldahl method (Nelson \& Sommers, 1973). Nitrogen resorption efficiency was calculated by:

$\operatorname{NRE}(\%)=\left[\left(\mathrm{N}_{\text {mature green }}-\mathrm{N}_{\text {senescent }}\right) / \mathrm{N}_{\text {mature }}\right.$ green $] * 100$, where: $\mathrm{NRE} \stackrel{\text { mature green }}{=}$ Nitrogen resorption efficiency, $\mathrm{N}_{\text {mature green }}=$ Nitrogen in mature green leaves, $\mathrm{N}_{\text {senescent }}=$ Nitrogen in senescent leaves (Pugnaire \& Chapin, 1993).

Nitrogen use efficiency was calculated by: NUE (g of dry mass $\mathrm{mg}^{-1}$ of nitrogen $)=1 /\left[\mathrm{N}_{\text {mature green }}(1-\right.$ $r)$ ], where: $\mathrm{NUE}=$ Nitrogen use efficiency, $\mathrm{N}_{\text {mature green }}$ $=$ total nitrogen concentration in mature green leaves and $r=$ NRE expressed in terms of a fraction (Aerts et al., 1999).

The nitrogen concentration in senescent leaves was used as an indicator of nitrogen resorption proficiency (Killingbeck, 1996).

\section{Leaf longevity and nitrogen conservation mecha-} nisms, under different availability of nitrogen

In the second experiment, seeds of both species were germinated in plastic boxes, in growth chambers kept at a controlled temperature of $30^{\circ} \mathrm{C}$, under continuous daylight, for approximately ten days. The plants were selected and planted individually in $5 \mathrm{~L}$ plastic pots, and kept in the greenhouse with automatic

Table 1 - Physical characteristics of mature green and senescent leaves of Anacardium occidentale (A. occid.) and Bixa orellana (B. orell.) used in the analyses performed in this study.

\begin{tabular}{|c|c|c|c|c|c|c|}
\hline \multirow{2}{*}{ Species } & \multicolumn{2}{|c|}{ Leaf Area } & \multicolumn{2}{|c|}{ Fresh Mass } & \multicolumn{2}{|c|}{ Dry Mass } \\
\hline & A. occid. & B. orell. & A. occid. & B. orell. & A. occid. & B. orell. \\
\hline & 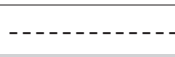 & - & - - - & - & - & - \\
\hline \multicolumn{7}{|l|}{ Kind of Leaf: } \\
\hline Mature green & $158 \pm 28$ & $204 \pm 32$ & $4.0 \pm 0.7$ & $3.5 \pm 0.7$ & $1.2 \pm 0.2$ & $1.2 \pm 0.3$ \\
\hline Senescent & $136 \pm 27$ & $171 \pm 25$ & $3.2 \pm 0.6$ & $2.4 \pm 0.3$ & $0.9 \pm 0.1$ & $0.8 \pm 0.2$ \\
\hline
\end{tabular}

Mean values \pm standard deviation of five replicates each comprised of three leaves. 
irrigation under natural light and temperature conditions. The study was carried out using three leaves from each individual plant and with ten individuals per treatment.

The following substrates were used: (i) clayey soil material (two parts soil / one part sand), with $250 \mathrm{~mL}$ of Hoagland and Arnon nutrient solution (Hoagland \& Arnon, 1938) added monthly to each pot, and (ii) previously washed sand material, with $250 \mathrm{~mL}$ of Hoagland and Arnon nutrient solution without N, added weekly to each pot (Hoagland \& Arnon, 1938). Irrigation was suspended $24 \mathrm{~h}$ before adding the nutrient solutions to avoid dilution of the solutions and began again $24 \mathrm{~h}$ after their application.

Leaf life spans, nitrogen resorption efficiency, nitrogen resorption proficiency and nitrogen use efficiency were monitored according to the protocol described above. The senescent leaves used to calculate conservation mechanism analyses were collected as they fell and stored in a freezer at $-20^{\circ} \mathrm{C}$, until analysis.

At the end of experiment (after 336 days) the concentrations of nitrogen (analyzed by the Kjeldahl method (Bremner,1996)) in the clay soil material, were 2.8 and $3.1 \mathrm{~g} \mathrm{~kg}^{-1}$ of dry mass for B. orellana and $A$. occidentale respectively, and in the sandy soil material $0.4 \mathrm{~g} \mathrm{~kg}^{-1}$ of dry mass for both species.

\section{Statistical analyses}

Statistical analyses were performed using the software SAS Institute (1990). The data were subjected to an analysis of variance and the means compared for significant differences by Tukey's test $(p<0.05)$. Percentage data in nitrogen resorption efficiency analy- ses were converted into arcsine (Montgomery, 1992), and analysis of variance was then applied. Plants cultivated under different nitrogen availability were submitted to a Two Way ANOVA. When there was a significant interaction of both factors (substrate and species), the data were submitted to simple analysis of variance followed by a Tukey's pairwise means comparison tests $(p<0.05)$.

\section{RESULTS AND DISCUSSION}

Greater leaf longevity in some species is per se a mechanism of nutrient economy, since it reduces mineral nutrient losses (Carrera et al., 2000; 2003), as the removal of minerals before leaf abscission is not complete in any type of plant (Chabot \& Hicks, 1982). Although $A$. occidentale is a deciduous species, its leaves had a greater leaf life span than those of the evergreen species (Table 2). Species that change leaves less frequently may be more successful in colonizing less fertile environments (Givnish, 2002).

There are no data in the literature relating rupture strain of leaves with leaf life span. A greater rupture strain was needed to break the leaves of $A$. occidentale compared to those of $B$. orellana (Table 2). A. occidentale also revealed greater values of leaf mass per area compared to $B$. orellana, which is consistent with the earlier observations that species showing greater leaf longevity present a greater leaf mass per area (Reich et al., 1992; Castro-Diez et al., 2000; Givnish, 2002; Wright et al., 2002; Prior et al., 2003; Ishida et al., 2006). Therefore, the observation that evergreen species tend to have leaves with an increased mass to the area ratio, which allows these leaves to

Table 2 - Mean values of leaf life span, leaf mass per area, leaf rupture strain and concentrations of total chlorophyll, total nitrogen, and total soluble proteins in mature green leaves. Nitrogen resorption efficiency (NRE), total nitrogen in senescent leaves, and nitrogen use efficiency (NUE) of mature trees of Anacardium occidentale and Bixa orellana. $\mathrm{DM}=$ dry mass, $\mathrm{FM}=$ fresh mass.

\begin{tabular}{lcc}
\hline \multirow{2}{*}{ Variable } & \multicolumn{2}{c}{ Species } \\
\cline { 2 - 3 } & Anacardium occidentale & Bixa orellana \\
\hline Leaf life span (days) & $206.20 \mathrm{a}$ & $109.33 \mathrm{~b}$ \\
Leaf mass per area $\left(\mathrm{mg} \mathrm{cm}^{-2}\right)$ & $7.40 \mathrm{a}$ & $5.70 \mathrm{~b}$ \\
Rupture strain $(\mathrm{N})$ & $4.39 \mathrm{a}$ & $2.09 \mathrm{~b}$ \\
Chlorophyll $\left(\mathrm{g} \mathrm{mg}^{-1} \mathrm{DM}\right)$ & $7.86 \mathrm{a}$ & $11.16 \mathrm{a}$ \\
Nitrogen in mature green leaves $\left(\mathrm{mg} \mathrm{g}^{-1} \mathrm{DM}\right)$ & $21.84 \mathrm{~b}$ & $27.66 \mathrm{a}$ \\
Proteins (mg g $\left.{ }^{-1} \mathrm{FM}\right)$ & $0.64 \mathrm{~b}$ & $0.75 \mathrm{a}$ \\
${ }^{\S} \mathrm{NRE}(\%)$ & $44.4 \mathrm{a}$ & $42.3 \mathrm{a}$ \\
Nitrogen in senescent leaves $\left(\mathrm{mg} \mathrm{g}^{-1} \mathrm{DM}\right)$ & $10.9 \mathrm{~b}$ & $15.0 \mathrm{a}$ \\
NUE $(\mathrm{g} \mathrm{DM} \mathrm{mg}$ & $0.94 \mathrm{a}$ & $0.68 \mathrm{~b}$ \\
\hline
\end{tabular}

Different letters indicate differences between species (Tukey $p<0.05$ ). ${ }^{\S}$ NRE values are presented in $\%$, although statistical analysis was carried out on values transformed to arcsine for achieving the statistical letters. 
resist adverse conditions for a longer time (Gates 1914 in Chabot \& Hicks, 1982), can also be applied to $A$. occidentale if one considers that Gates may have used the expression "evergreen species" as a synonym for species having greater leaf longevity. As well as contributing towards greater leaf resistance, a greater leaf mass per area of $A$. occidentale may also be involved in the adaptation to the dry environment of the natural habitat of this species, since a reduction in leaf area relative to leaf mass tends to reduce transpiration.

Species that have leaves with a longer life span show a lower level of total nitrogen (Chabot \& Hicks, 1982; Diehl et al., 2003; Prior et al., 2003; Haddad et al., 2004; Ishida et al., 2006; Lima et al., 2006a; Sakata et al., 2006), chlorophyll (Prior et al., 2003; Haddad et al., 2004; Lima et al., 2006a) and soluble proteins (Haddad et al., 2004; Takashima et al., 2004; Lima et al., 2006a) in comparison to species that have leaves with a shorter leaf life span. The longer leaf life span and the lower nutrient content of the leaves are important characteristics in making the colonization of low fertility soils possible (Carrera et al., 2003). Although the differences in chlorophyll contents between $A$. occidentale and $B$. orellana were not significant (Table 2), our data are consistent with this proposal, since $A$. occidentale showed lower protein and total nitrogen content in mature green leaves than $B$. orellana (Table 2 ).

Greater leaf longevity may be accompanied by greater nitrogen resorption efficiency. The resorption efficiency shows the degree in which the nutrients are conserved in the leaves, thus minimizing the need for subsequent absorption of them. This parameter relates the nutrient content in mature green leaves to their resorption (Killingbeck, 1996). However, data in the literature that relate leaf longevity and nitrogen resorption efficiency are conflicting. Killingbeck (1996) ascribes the lack of consistency in the data to environmental fluctuations that occur from one year to the next. In the present study there was no difference between the results of the two species (Table 2).

Resorption proficiency is quantified by the absolute value by which nutrients are reduced in senescent leaves. Thus, the lower the concentration of a nutrient in senescent leaves, the greater is its resorption proficiency (Killingbeck, 1996). There is little data in the literature relating leaf longevity to resorption proficiency. Oleksyn et al. (2003) and Lima et al. (2006b) verified that the species with the highest leaf life span presented the greatest nitrogen resorption proficiency. Our results are consistent with these observations since nitrogen resorption proficiency for $A$. occidentale was higher than for $B$. orellana (Table 2 ), indicating that $A$. occidentale losses this element to the environment are smaller.
There are indications that species with leaves with higher longevity are able to produce more organic matter per unit of mineral nutrient than species with lower leaf longevity (Aerts et al., 1999; Haddad et al., 2004; Milla et al., 2005). This ratio represents the nutrient use efficiency (Vitousek, 1982). The residence time of the nutrient in the leaf, an important component of efficiency in the use of nutrients, depends on leaf longevity and the quantity of reabsorbed nutrients before leaf abscission (Aerts, 1990). Nitrogen use efficiency for $A$. occidentale was higher than for $B$. orellana (Table 2). A. occidentale loses leaves less frequently, loses less nitrogen to the environment in the abscised leaves and manages to produce organic material using proportionally less nitrogen when compared to $B$. orellana. These characteristics may be contributing to the adaptation of this species to soils with a low availability of this element.

In the second experiment, there was a significant interaction between the type of substrate and the species in the nitrogen analysis of the senescent leaves, and in the nitrogen use efficiency and resorption efficiency (Table 3). Several authors believe that high resorption efficiency helps certain species to adapt to less fertile environments (e.g. Pugnaire \& Chapin, 1993). However, when an attempt is made to relate this parameter to soil fertility, the results are controversial (Cordell et al., 2001; Carrera et al., 2003; Feller et al., 2003; Distel et al., 2003; Richardson et al., 2004; Lima et al., 2006b). Nitrogen resorption efficiency data did not have a clear relationship with the availability of this element in the substrate (Table 3). Greater values were found in $A$. occidentale cultivated in clay soil and in $B$. orellana cultivated in sandy soil. When both species were compared in the same substrate, $A$. occidentale showed greater values only in the clay soil (Table 3 ).

Resorption proficiency is considered a more stable indicator of natural selection, acting to reduce the loss of nutrients in less fertile environments, when compared to resorption efficiency. Since resorption efficiency analyses the relative concentration of nutrients between senescent and mature green leaves, its values may be high even though there is still a large amount of nutrients in the senescent leaves (Killingbeck, 1996). The fertility of the substrate affected nitrogen resorption proficiency and nitrogen use efficiency of both species in such a way that, under less fertile conditions, these mechanisms of nutrient conservation were more efficient (Table 3 ). This demonstrates that both species have the plasticity that allows them to adjust to changes in the type of substrate. Leaf longevity of both species was not affected by the type of substrate (Table 3 ), indicating that this characteristic must be intrinsically determined. 
Table 3 - Factorial analysis of total nitrogen in senescent leaves, nitrogen use efficiency (NUE), nitrogen resorption efficiency (NRE) and leaf life span (LLS) in the pot experiments. The interaction between species Anacardium occidentale (A.oc) or Bixa orellana (B.or) and substrate (clay and sand or sand) is shown by F values followed by level of significance: $* 5 \%, * * 1 \%, * * 0.1 \%$. NS $=$ non significant, $\mathrm{DM}=$ dry mass.

\begin{tabular}{|c|c|c|c|c|c|}
\hline \multirow{3}{*}{$\begin{array}{l}\text { F values } \\
\text { Species }\end{array}$} & \multicolumn{2}{|c|}{$\mathrm{NRE}^{\S}$} & Nitrogen & NUE & LLS \\
\hline & \multicolumn{2}{|c|}{$10.43 * *$} & $6.28 *$ & $13.94 * * *$ & $2.77 \mathrm{NS}$ \\
\hline & A.oc - & - B.or & A.oc - B.or & A.oc - B.or & A.oc - B.or \\
\hline & -...... & \% - - - & $\ldots m g g^{-1}$ DM -... & $\mathrm{g} \mathrm{DM} \mathrm{mg}^{-1}$ Nitrogen & -..-- days -..-- \\
\hline \multicolumn{6}{|l|}{ Soil: } \\
\hline Clay & $51.5 \mathrm{aA}-$ & $-37.5 \mathrm{bB}$ & $12.2 \mathrm{bA}-15.8 \mathrm{aA}$ & $0.89 \mathrm{aB}-0.65 \mathrm{bB}$ & $225 a-110 b$ \\
\hline Sandy & $46.5 \mathrm{aB}-$ & $44.4 \mathrm{aA}$ & $10.4 \mathrm{bB}-11.7 \mathrm{aB}$ & $0.96 \mathrm{aA}-0.87 \mathrm{bA}$ & $274 a-107 b$ \\
\hline
\end{tabular}

Means followed by different small letters are different at the species level in the same substrate, and different capital letters indicate differences between substrates for the same species (Tukey $p<0.05$ ). ${ }^{\S} \mathrm{NRE}$ values are presented in $\%$, although statistical analysis was carried out on values transformed to arcsine for achieving the statistical letters

When comparing both species in the same substrate, the resorption proficiency, nitrogen use efficiency and leaf longevity were all greater in $A$. occidentale (Table 3), indicating a higher potential in conserving nitrogen. Species adapted to fertile environments invest more in the acquisition of resources than species adapted to less fertile habitats, which invest more in the conservation of these resources (Westoby et al., 2002; Pujol et al., 2008).

In summary, although $A$. occidentale is considered a deciduous species, its leaves had a higher life span in comparison to the evergreen $B$. orellana. Therefore, in neotropical regions, the leaf deciduousness of the species does not necessarily have a direct relationship with leaf longevity. Many species of tropical rain forests are evergreen, although their leaves have leaf life spans of less than a year and show similar characteristics to deciduous species (Reich et al., 1991). The data observed for B. orellana fit these observations perfectly. Regarding to the results obtained for $A$. occidentale, Reich et al (1992) discuss that deciduous species, with a leaf life span of nine to ten months, are probably more similar to evergreen species than deciduous species with leaf life spans of only two to three months. It is possible that the greater capacity that $A$. occidentale has for conserving nitrogen in its leaves may contribute to its occurrence in low fertility soils. Other factors may also be involved in the adaptation of this species to less fertile soils of the northeast region in Brazil. Givnish (2002) highlights the importance of verifying the allocation of resources in the underground organs. Thus, plants adapted to less fertile environments may have an underground system with a good mineral storage capacity. Or they may even have a more extensive root system that would allow more efficient absorption of minerals from the soil. As well as having less fertile soils, the natural environment of $A$. occidentale is also arid. The adapta- tion to arid environments implies in a greater investment in roots to replenish water lost by transpiration (Givnish, 2002). Thus, further studies related to the importance of the root system of $A$. occidentale in the adaptation of this species to its native habitat are necessary.

\section{ACKNOWLEDGEMENTS}

To Dr. Odair Bovi for granting permission to collect leaves of B. orellana, and to Prof. Ladaslav Sodek for revising the English version of the manuscript. Guilherme Corte is grateful to the CNPq for the award of PIBIC fellowship.

\section{REFERENCES}

AERTS, R. Nutrient use efficiency in evergreen and deciduous species from heathlands. Oecologia, v.84, p.391-397, 1990.

AERTS, R.; VERHOEVEN, J.T.A.; WhIGHAM, D.F. Plantmediated controls on nutrient cycling in temperate fens and bogs. Ecology, v.80, p.2170-2181, 1999.

BRADFORD, M.M. A rapid and sensitive method for the quantization of microgram quantities of protein utilizing the principle of protein-dye binding. Analytical Biochemistry, v.72, p.248-254, 1976.

BREMNER, J.M. Nitrogen-Total. In: KLUTE, A.; WEAVER, R.W.; MICKELSON, S.H.; SPARKS, D.L.; BARTELS, J.M. (Ed.) Methods of soil analysis. Madison: SSSA, 1996. chap. 3, p.1085-1121. (Chemical Methods. Book Series, 5).

CARRERA, A.L.; SAIN, C.L.; BERTILLER, M.B. Patterns of nitrogen conservation in shrubs and grasses in the Patagonian Monte, Argentina. Plant and Soil, v.224, p.185-193, 2000.

CARRERA, A.L.; BERTILLER, M.B.; SAIN, C.L.; MAZZARINO, M.J. Relationship between plant nitrogen conservation mechanisms and the dynamics of soil nitrogen in the arid Patagonian Monte, Argentina. Plant and Soil, v.255, p.595-604, 2003.

CASTRO-DÍEZ, P.; PUYRAVAUD, J.P.; CORNELISSEN, J.H.C. Leaf structure and anatomy as related to leaf mass per area variation in seedlings of a wide range of woody plant species and types. Oecologia, v.124, p.476-486, 2000.

CHABOT, B.F.; HICKS, D.J. The ecology of leaf life spans. Annual Review of Ecology and Systematics, v.13, p.229-259, 1982.

CORDELL, S.; GOLDSTEIN, G.; MEINZER, F.C.; VITOUSEK, P.M. Regulation of leaf life-span and nutrient-use efficiency of Metrosideros polymorpha trees at two extremes of a long chronosequence in Hawaii. Oecologia, v.127, p.198-206, 2001. 
DAL FABBRO, I.M.; MURASE, H.; SEGERLIND, L.J. Strain failure of apple, pear and potato tissue. In: SUMMER MEETING OF THE AMERICAN SOCIETY OF AGRICULTURAL ENGINEERS, Saint Joseph, 1980. Proceedings. Saint Joseph, 1980.

DIEHL, P.; MAZZARINO, M.J.; FUNES, F.; FONTENLA, S.; GOBBI, M.; FERRARI, J. Nutrient conservation strategies in native Andean-patagonian forests. Journal of Vegetation Science, v.14, p.63-70, 2003.

DiSTEL, R.A.; MORETTO, A.S.; DIDONÉ, N.G. Nutrient resorption from senescing leaves in two Stipa species native to central Argentina. Austral Ecology, v.28, p.210-215, 2003.

FELLER, I.C.; McKEE, K.L.; WHIGHAM, D.F.; O'NEILL, J.P. Nitrogen vs. phosphorus limitation across an ecotonal gradient in a mangrove forest. Biogeochemistry, v.62, p.145-175, 2003.

GIVNISH, T.J. Adaptive significance of evergreen vs. deciduous leaves: solving the triple paradox. Silva Fenica, v.36, p.703-743, 2002.

HADDAD, C.R.B.; LEMOS, D.P.; MAZZAFERA, P. Leaf life span and nitrogen in semideciduous forest tree species (Croton priscus and Hymenaea courbaril). Scientia Agricola, v.61, p.462465, 2004

HIKOSAKA, K. Leaf canopy as a dynamic system: ecophysiology and optimality in leaf turnover. Annals of Botany, v.95 p.521$533,2005$.

HISCOX, J.D.; ISRAELSTAM, G.F. A method for the extraction of chlorophyll from leaf tissue without maceration. Canadian Journal of Botany, v.57, p.1332-1334, 1979.

HOAGLAND, D.R.; ARNON, D.I. The water culture method for growing plants without soil. Davis: University of California Agricultural Experimental Station, 1938, (Bulletin, 347).

ISHIDA, A.; DILOKSUMOUN, S.; LADPALA, P.; STAPORN, D.; PANUTHAI, S.; GAMO, M.; YAZAKI, K.; ISHIZUKA, M.; PUANGCHIT, L. Contrasting seasonal leaf habits of canopy trees between tropical dry-deciduous and evergreen forests in Thailand. Tree Physiology, v.26, p.643-656, 2006.

KILLINGBECK, K.T. Nutrients in senesced leaves: keys to the search for potential resorption and resorption proficiency. Ecology, v.77, p.1716-1727, 1996.

LAL, C.B.; ANAPURNA, C.; RAGHUBANSHI, A.S.; SINGH, J.S. Effect of leaf habit and soil type on nutrient resorption and conservation in woody species of a dry tropical environment. Canadian Journal of Botany, v.79, p.1066-1075, 2001

LICHTENTHALER, B.K.; WELLBURN, A.R. Determination of total carotenoids and chlorophylls a and b of leaf extracts in different solvents. Biochemical Society Transactions, v.11, p.591-592, 1983

LIMA, A.L.S.; ZANELLA, F.; SCHIAVINATO, M.A.; HADDAD, C.R.B. Nitrogenous compounds, phenolic compounds and physical aspects of leaves: comparison of deciduous and semideciduous arboreal legumes. Scientia Agricola, v.63, p.40-45, 2006a.

LIMA, A.L.S.; ZANELLA, F.; SCHIAVINATO, M.A.; HADDAD, C.R.B. $\mathrm{N}$ availability and mechanisms of $\mathrm{N}$ conservation in deciduous and semideciduous tropical forest legume trees. Acta Botanica Brasilica, v.20, p.625-632, 2006b.

LORENZI, H. Árvores brasileiras. 3 ed. Nova Odessa: Editora Plantarum, 2000. 352p.

MILlA, R.; CASTRO-DIEZ, P.; MAESTRO-MARTINEZ, M.; MONTSERRAT-MARTI, G. Environmental constraints on phenology and internal nutrient cycling in the Mediterranean winter-deciduous shrub Amelanchier ovalis Medicus. Plant Biology, v.7, p.182-189, 2005

MONTGOMERY, D.C. Introduction to linear regression analysis. 2 ed. New York: John Wiley, 1992. p 544 (Wiley Series in Probability and Mathematical Statistics).

MORELLATO, L.P.C.; LEITÃO-FILHO, H.F. Reproductive phenology of climbers in a southeastern Brazilian forest. Biotropica, v.28, p.180-191, 1996.

MORELLATO, L.P.C.; TALORA, D.C.; TAKAHASI, A.; BENCKE, C.C.; ROMERA, E.C.; ZIPARRO, V.B. Phenology of Atlantic rain forest trees: a comparative study. Biotropica, v.32, p.811823,2000
NELSON, D.W.; SOMMERS, L.E. Determination of the total nitrogen in plant material. Agronomy Journal, v.65, p.109112, 1973.

OLEKSYN, J.; REICH, P.B.; ZYTKOWIAK, R.; KAROLEWSKI, P.; TJOELKER, M.G. Nutrient conservation increases with latitude of origin in European Pinus sylvestris populations. Oecologia, v.136, p.220-235, 2003.

PIEDADE, S.; FABBRO, I.M.D.; VIDAL, B.C.; GAMGA, R. Ensaio uniaxial de tração de tendões de músculos grácil e semitendinoso. Acta Ortopédica Brasileira, v.9, p.5-11, 2001.

PRIOR, L.D.; EAMUS, D.; BOWMAN, D.M.J.S. Leaf attributes in the seasonally dry tropics: a comparison of four habitats in northern Australia. Functional Ecology, v.17, p.504-515, 2003.

PUGNAIRE, F.I.; CHAPIN, F.S. Controls over nutrient resorption from leaves of evergreen Mediterranean species. Ecology, v.74, p.124-129, 1993

PUJOL, B.; SALAGER, J-L.; BELTRAN, M.; BOUSQUET, S.; McKEY, D. Photosynthesis and leaf structure in domesticated cassava (Euphorbiaceae) and close wild relative: have leaf photosynthetic parameters evolved under domestication? Biotropica, v.40, p.305-312, 2008.

READ, J.; EDWARDS, C.; SANSON, G.D.; ARANWELA, N. Relationships between sclerophylly, leaf biomechanical properties and leaf anatomy in some Australian heath and forest species. Plant Biosystems, v.134, p.261-277, 2000.

REICH, P.B.; UHL, C.; WALTERS, M.B., ELLSWORTH, D.S. Leaf lifespan as a determinant of leaf structure and function among 23 tree species in Amazonian forest communities. Oecologia, v.86, p.16-24, 1991.

REICH, P.B.; WALTERS, M.B.; ELLSWORTH, D.S. Leaf lifespan in relation to leaf, plant, and stand characteristics among diverse ecosystems. Ecological Monographs, v.62, p.365-392, 1992.

RICHARDSON, S.J.; PELTZER, D.A.; ALLEN, R.B.; McGLONE, M.S.; PARFITT, R.L. Rapid development of phosphorus limitation in temperate rainforest along the Franz Josef soil chronosequence. Oecologia, v.139, p.267-276, 2004.

SAKATA, T.; NAKANO, T.; IINO, T.; YOKOI, Y. Contrastive seasonal changes in ecophysiological traits of leaves of two perennial Polygonaceae herb species differing in leaf longevity and altitudinal distribution. Ecological Research, v.21, p.633640, 2006.

SAS INSTITUTE. SAS/STAT user's guide: version 8. Cary: SAS Institute, 1990. CD-ROM.

SMART, C.M. Gene expression during leaf senescence. New Phytologist, v.126, p.419-448, 1994.

SOIL SURVEY STAFF. Keys to soil taxonomy. 9 ed. Washington, D.C.: Natural Resources Conservation Service, US Department of Agriculture, 2003. $331 \mathrm{p}$.

TAKASHIMA, T.; HIKOSAKA, K.; HIROSE, T. Photosynthesis or persistence: nitrogen allocation in leaves of evergreen and deciduous Quercus species. Plant and Cell Environment, v.27, p.1047-1054, 2004.

VITOUSEK, P.M. Litterfall, nutrient cycling and nutrient limitation in tropical forests. Ecology, v.65, p.285-298, 1982.

WESTOBY, M.; FALSTER, D.S.; MOLES, T.; VESK, P.A; WRIGHT,

I.J. Plant ecological strategies: some leading dimensions of variation between species. Annual Review of Ecology and Systematics, v.33, p.125-159, 2002.

WRIGHT, I.J.; WESTOBY, M.; REICH, P.B. Convergence towards higher leaf mass per area in dry and nutrient-poor habitats has different consequences for leaf lifespan. Journal of Ecology, v.90, p.534-543, 2002.

WRIGHT, I.J.; WESTOBY, M. Nutrient conservation, resorption and lifespan: leaf traits of Autralian sclerophyll species. Functional Ecology, v.17, p.10-19, 2003.

Received July 18, 2008

Accepted May 19, 2009 